\title{
Chronic Use of Anabolic Steroids and the Effects on the Neuronal Density of the Cerebral Cortex and Hippocampus in Mice
}

\author{
Dauanda Kécia Silva ${ }^{1}$, Alessandra Esteves ${ }^{1, ~ *}$, Flávia Da Ré Guerra ${ }^{1}$, Evelise Aline Soares ${ }^{2}$, \\ Denismar Alves Nogueria ${ }^{3}$, Petrus Pires Marques ${ }^{4}$, Wagner Costa Rossi Junior ${ }^{1}$ \\ ${ }^{1}$ Institute of Biomedical Sciences, Department of Anatomy, Federal University of Alfenas, Alfenas, Brazil \\ ${ }^{2}$ Medical School, Federal University of Alfenas, Alfenas, Brazil \\ ${ }^{3}$ Institute of Exact Sciences, Department of Statistics, Federal University of Alfenas, Alfenas, Brazil \\ ${ }^{4}$ Medical School, Department of Morphology, José Vellano University, Unifenas, Alfenas, Brazil
}

Email address:

aesteves@unifal-mg.edu.br(A. Esteves), aesteves015@gmail.com(A. Esteves)

${ }^{*}$ Corresponding author

\section{To cite this article:}

Dauanda Kécia Silva, Alessandra Esteves, Flávia Da Ré Guerra, Evelise Aline Soares, Denismar Alves Nogueria, Petrus Pires Marques, Wagner Costa Rossi Junior. Chronic Use of Anabolic Steroids and the Effects on the Neuronal Density of the Cerebral Cortex and Hippocampus in Mice. American Journal of Sports Science. Vol. 6, No. 3, 2018, pp. 122-129. doi: 10.11648/j.ajss.20180603.18

Received: August 8, 2018; Accepted: August 21, 2018; Published: September 11, 2018

\begin{abstract}
This study analyzed the effects of the chronic use of these drugs on the neuronal density of mice cerebral cortex and hippocampus. Materials and methods: 40 male Swiss mice were used, divided into 4 groups $(\mathrm{n}=10)$ : GI-Control $\left(0,02 \mathrm{ml} / \mathrm{Kg} /\right.$ week of saline solution), GII- treated with anabolic steroid Durateston ${ }^{\circledR}(83,3 \mathrm{mg} / \mathrm{Kg} /$ week $)$ GIII- treated with anabolic steroid Deca Durabolin ${ }^{\circledR}(16,6 \mathrm{mg} / \mathrm{Kg} /$ week $)$ e GIV- treated with the two anabolic steroids, concomitantly. The mice were treated for sixty days (60) and practiced swimming three times a week. The brain fragments were processed following the standardized sequence in conventional histological procedures and stained using cresyl violet. For the neuronal density analysis, the simple random count methodology was used. Results: Data revealed a significant reduction in the neuronal density of the groups treated with anabolic steroids, the limbic area had an estimated decrease of $16.44 \%$ in group III and $29.21 \%$ in group IV; the motor area the groups II, III, and IV presented a reduction of $17.63 \%, 15.35 \%$, and $12.23 \%$, and in the sensory area $15.22 \%, 16.41 \%$ and $21.59 \%$, respectively; the groups II, III, and IV of the Ca1 area of the hippocampus showed a neuronal loss of $23.5 \%, 27.8 \%$, and $36.36 \%$, while groups II, III and IV of the Ca2 area there was a reduction of $10.37 \%$, $11.83 \%$, and $16.34 \%$. In conclusion, the chronic use of AAS can be harmful to the nervous system since the neuronal reduction can bring structural and functional damages with possible consequences the whole organism.
\end{abstract}

Keywords: Steroids, Cerebral Cortex, Hippocampus, Neuronal Density

\section{Introduction}

Anabolic steroids (AS) are synthetic testosterone derivatives that last longer than physiological androgens in the body. Anabolic-androgenic steroid (AAS), agents are doping substances which are commonly used in sports and its abuse is associated with several medical and behavioral adverse effects. $[1,2,3]$

In the last decades, the importance given to the body attractiveness increased drastically. Such phenomenon led to the upsurge of new techniques aiming body aesthetics, such as diets, muscle training, and plastic surgeries. Men and Women have been investing every time more resources and time in products directed to beauty maintenance. Among these products are the "body image" drugs, including the AAS. $[4,5]$

The AAS use is not only aesthetic. Indiscriminate use by athletes striving for performance improvement is widely reported, not only by professionals but also by amateurs, especially bodybuilders $[6,7]$. 
Clinically, the androgenic-anabolic steroids are frequently used to treat male infertility, kidney diseases, aplastic anemia, AIDS acquired asthenia, osteoporosis, as a coadjuvant in the treatment of some cancers, among others [8].

Although one in every three AAS users develop some physical disturbance, the psychological and central nervous system effects of such drugs are yet not very well described. Nevertheless, it is already known that the euphoric effects are less lasting than those of most addictive substances $[9,10]$

Research using male rodents have demonstrated that testicle hormones play an essential role in the neuron circuit organization and behavior during the adolescence. Furthermore, other studies showed that chronic inadequate use of some AAS (testosterone, nandrolone, stanozolol) increased aggressive and sexual expression in rats, which even persisted for several weeks after treatment interruption. These data combined suggest that AAS use during adolescence can lead to behavioral effects more pronounced and lasting than in adults $[11,12]$. Different researchers also indicate that AAS use increases the chances of neuron death in different brain regions in mice $[13,14,15]$.

Due to the increase in the number of AAS users and by the effects on mental and physical health $[16,17,18]$, there is an increasing need for studying these substances. The present work aimed to bring more knowledge regarding the effect of two widely used anabolic-androgenic steroids in six different areas of the brain.

\section{Material and Methods}

The present research was approved by the Animal Ethics Committee, from the Federal University of Alfenas (UNIFAL-MG) approval number 496/2012. A total of 40 male Swiss mice were used, all of them 90 days old. Animals were caged individually in $30 \times 18 \times 12 \mathrm{~cm}$ plastic containers, with free access to mice chaw and water and kept under a 12 hours light-dark cycle.

The research contained a total of four experimental groups $(\mathrm{n}=10)$. GI-Animals treated with saline solution, $0.02 \mathrm{ml} /$ week (control group); GII- animals treated with Durateston, $83.3 \mathrm{mg} / \mathrm{kg} /$ week; GIII- animals treated with Deca Durabolin, $16.6 \mathrm{mg} / \mathrm{kg} /$ week; GIV- animals treated with the association of both the steroids, Durateston $83.3+$ Deca Durabolin $16.6 \mathrm{mg} / \mathrm{kg} /$ week. The applied doses were obtained through calculation considering the abusive AAS use, corresponding to supraphysiological doses, varying from 10 to 100 fold the therapeutical recommendations [19, 20].

Animals from all the groups were put to swim thrice a week (Mondays, Wednesdays, and Fridays) during the treatment period to mimic the exercise performed by athletes and gym adepts [21]. The animals swam in a plastic container measuring $43 \times 34 \times 26 \mathrm{~cm}$ for five minutes. After this time, mice were removed from the water, towel dried and put back in the respective container.

After experiment time, the animals were euthanized through anesthesia overdose, using Halothane, each encephalon removed, washed in water and stored in glass jars containing paraformaldehyde $4 \%$ in phosphate buffer $\mathrm{pH} 7.0$, $0.1 \mathrm{M}$ and kept immersed for a total of 24-hours.

Encephalon fragments were processed following standardized histological procedure $[13,15]$. To estimate the neuron density, simple random sampling method was used [22, 23, 24, 25].

Quantification values were analyzed using ANOVA followed by Tukey test $(p<0.05)$ using software GraphPad Prism.

\section{Results}

\subsection{Cortical Areas of the Brain}

In Table 1 shows the values of neuronal loss in the limbic, motor and sensitive brain cortex areas.

A significative reduction in neuron density can be observed in the limbic area of GIII (16.44\%) and GIV (29.21\%) compared to control. These same groups also presented neuron density inferior to GII (7.67\%).

Motor and sensitive areas analysis revealed that all experimental groups presented neuron density inferior to the control GI. The exact values are present in Table 1.

Table 1. Mean and standard deviation of neuron density and percentual loss of neurons in the limbic, motor, and sensitive areas from the groups analyzed.

\begin{tabular}{lll}
\hline Groups & Mean \pm SD & neuronal loss $(\%)$ \\
\hline GI & Limbic area & \\
GII & $23.72 \pm 3.39$ & $100 \%$ \\
GIII & $21.90 \pm 2.06$ & $7.67 \%$ \\
GIV & $19.87 \pm 1.69$ & $16.44 \%$ \\
& $16.79 \pm 1.05$ & $29.21 \%$ \\
GI & Motor area & \\
GII & $16.67 \pm 2.68$ & $100 \%$ \\
GIII & $13.73 \pm 1.96$ & $17.63 \%$ \\
GIV & $14.11 \pm 1.5$ & $15.35 \%$ \\
& $14.63 \pm 1.36$ & $12.23 \%$ \\
GI & Sensitive area & \\
GII & $22.79 \pm 3.04$ & $100 \%$ \\
GIII & $19.32 \pm 2.15$ & $15.22 \%$ \\
GIV & $19.05 \pm 1.94$ & $16.41 \%$ \\
\hline
\end{tabular}

The Figure 1 (A-D) shows images from slides from the limbic area and the same data is represented in Figure 1E. 

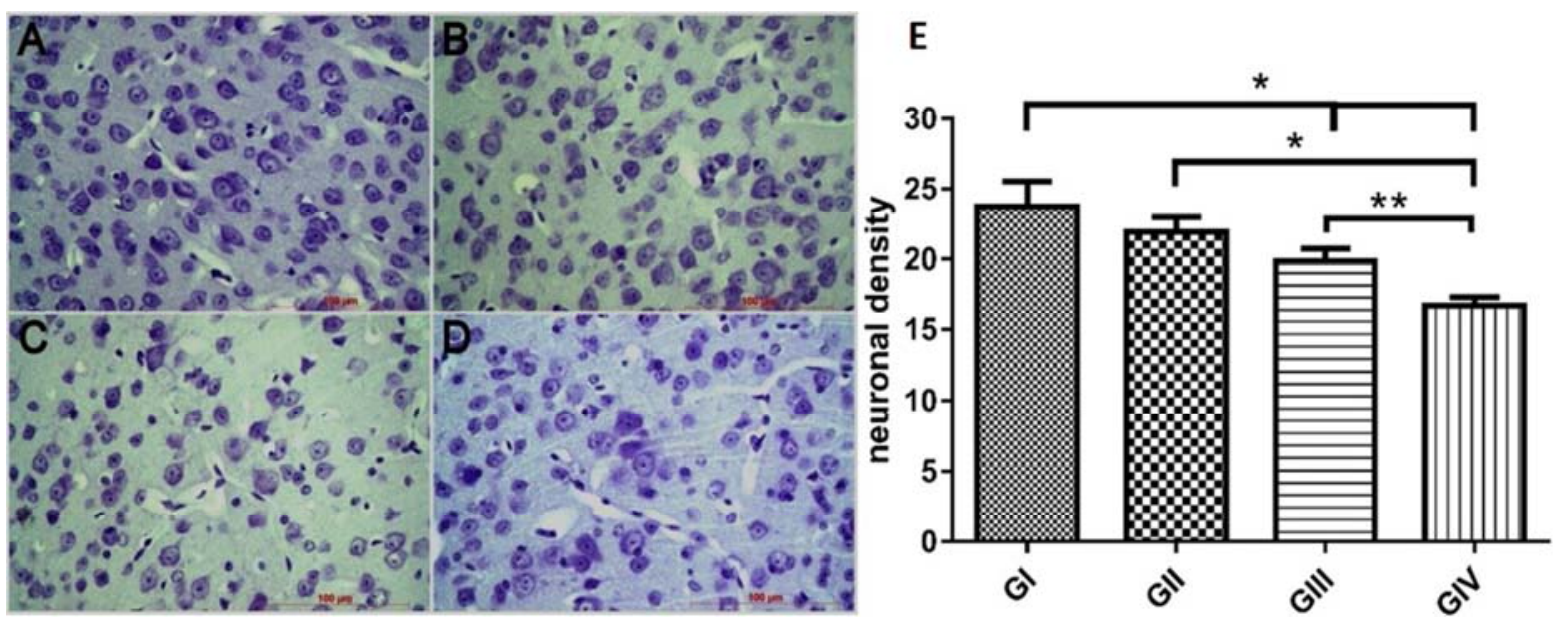

Figure 1. Photomicrography of the limbic area from the different groups. A: GI, B: GII, C: GIII e D: G IV. Staining used: Cresil violet. 400x magnification. (IE) Significative differences of the treated groups in the neuron density of limbic area; where GI $x$ GIII, GI $x$ GIV e GII $x$ GIV=p<0,0001 and GII $x$ GIV = $p<0,05$.

In Figure 2 (A, B, C, D) and 3 (A, B, C, D) respectively can be observed a comparison of the morphology from the motor and sensitive areas of the brain. Figures $2 \mathrm{E}$ and $3 \mathrm{E}$ illustrate the results of neuron density of the respective regions obtained from the animals of the different groups.
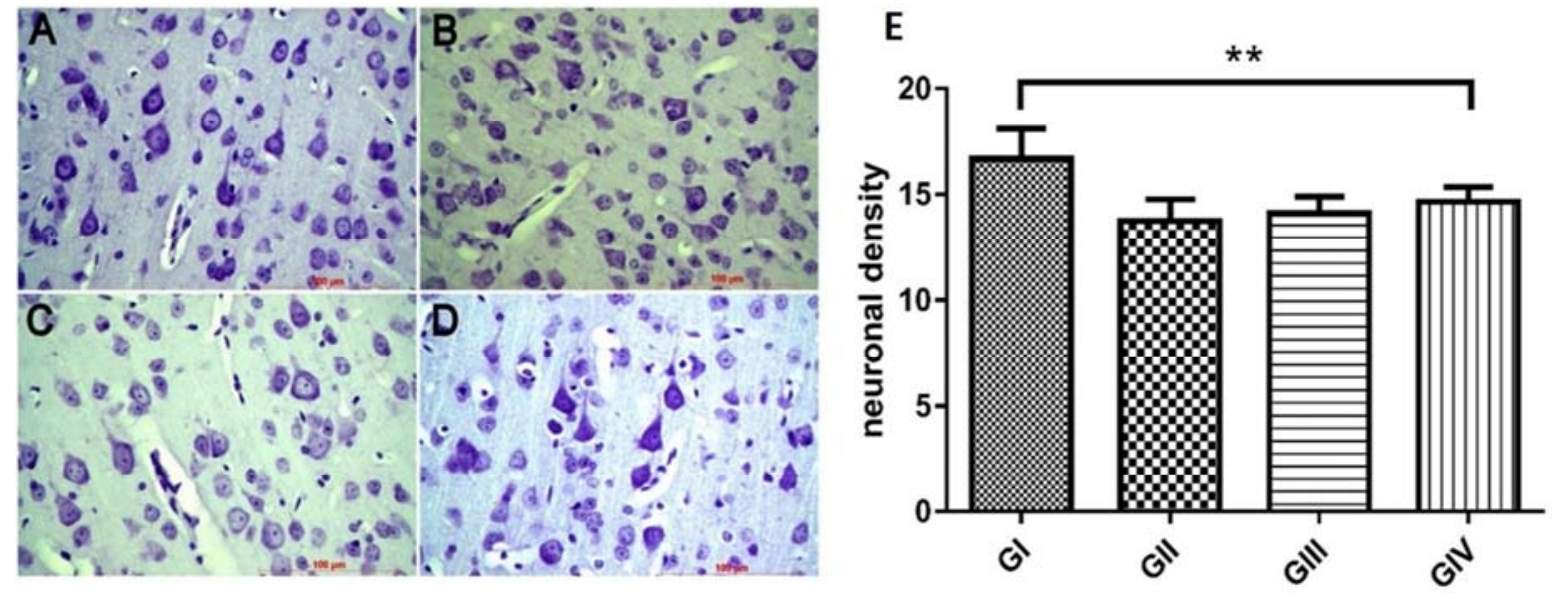

Figure 2. Photomicrography of the motor area from the different groups. A: GI, B: GII, C: GIII e D: G IV. Staining used: Cresil violet. $400 x$ magnification. (2E) Significative differences of the treated groups in the neuron density of motor area; where GIx GII=p<0,0001; GIx GII =p p<0,001 e GIx GIV =p<0,05.
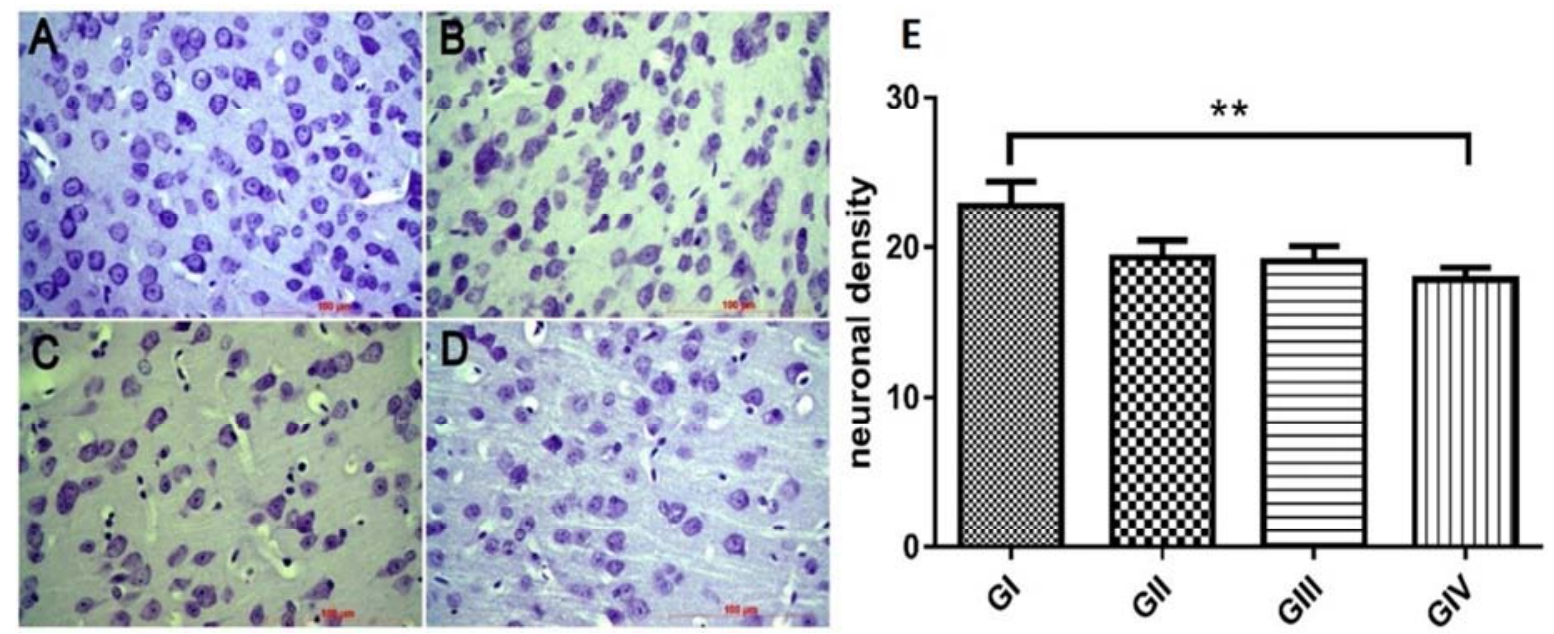

Figure 3. Photomicrography of the sensitive area from the different groups. A: GI, B: GII, C: GIII e D: G IV. Staining used: Cresil violet. 400x magnification. (3E) Significative differences of the treated groups in the neuron density of sensitive area; $p<0,0001$. 


\subsection{Hippocampus}

Table 2 contains the results from the means and standard deviation of neuron density, along with neuron loss in hippocampal areas $\mathrm{Ca} 1, \mathrm{Ca} 2$, and $\mathrm{Ca} 3$ of the different groups.

Table 2. Mean and standard deviation of neuron density and percentual loss of neurons in the hippocampal Ca1, Ca2, and Ca3 areas from the groups analyzed.

\begin{tabular}{lll}
\hline Groups & Mean \pm SD & Neuronal loss (\%) \\
\hline & Ca1 area & \\
GI & $5.83 \pm 1.32$ & $100 \%$ \\
GII & $4.46 \pm 1.35$ & $23.5 \%$ \\
GIII & $4.21 \pm 0.58$ & $27.8 \%$ \\
GIV & $3.71 \pm 0.71$ & $36.36 \%$ \\
& $\mathrm{Ca} 2$ area & \\
\hline
\end{tabular}

\begin{tabular}{lll}
\hline Groups & Mean \pm SD & Neuronal loss (\%) \\
\hline GI & $27.29 \pm 5.44$ & $100 \%$ \\
GII & $24.46 \pm 1.98$ & $10.37 \%$ \\
GIII & $24.06 \pm 2.17$ & $11.83 \%$ \\
GIV & $22.83 \pm 1.35$ & $16.34 \%$ \\
& Ca3 area & \\
GI & $23.52 \pm 4.37$ & $100 \%$ \\
GII & $22.50 \pm 2.47$ & $4.33 \%$ \\
GIII & $22.79 \pm 3.41$ & $3.1 \%$ \\
GIV & $21.74 \pm 2.49$ & $7.5 \%$ \\
\hline
\end{tabular}

The Figure 4 (A, B, C, D) it is observe a comparison between the morphology of the different groups in the area Ca1. The Cal area of all treated groups presented lower neuronal density than control, as it can be seen in Table 1 and Figure 4E.
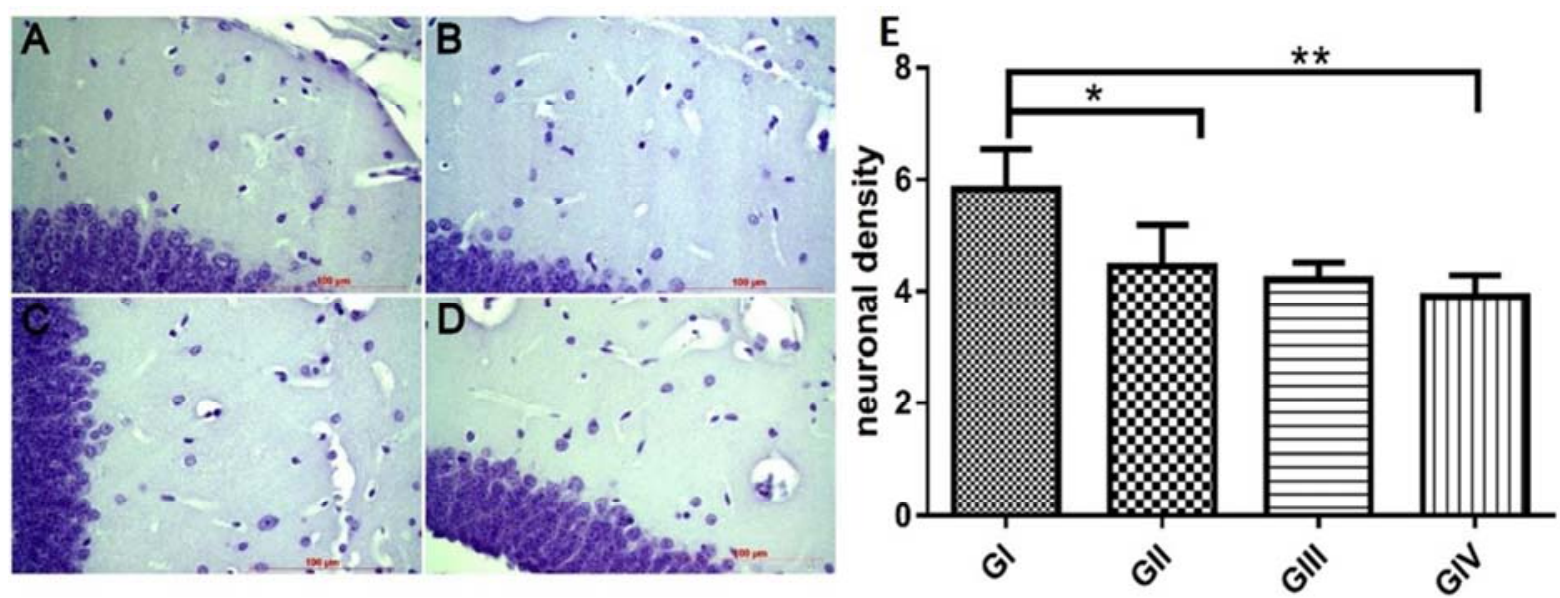

Figure 4. Photomicrography of the Cal area from the different groups. A: GI, B: GII, C: GIII e D: G IV. Staining used: Cresil violet. 400x magnification. (4E) Significative differences of the treated groups in the neuron density of Cal area; where **=p<0,0001 $e$ GI $x$ GII: *=p<0,001.

In area $\mathrm{Ca} 2$, once again it can be observed that the groups GII, GIII, and GIV presented a significative loss in neuron density, specially GIV, as it can be seen in Table 2. In Figure 5 (A, B, C, D) it can be observed a comparison between the morphology of the different groups in the area $\mathrm{Ca} 2$, along with a morphology comparison Figure 5E.
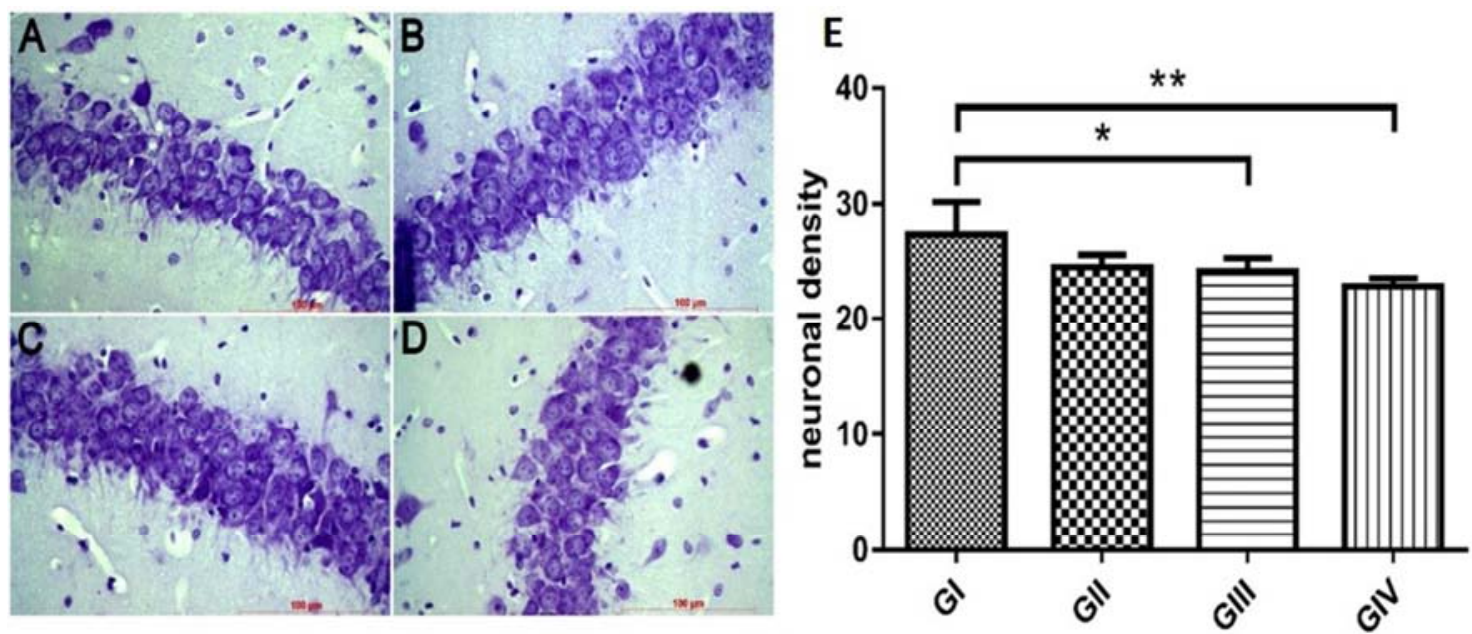

Figure 5. Photomicrography of the Ca2 area from the different groups. A: GI, B: GII, C: GIII e D: G IV. Staining used: Cresil violet. 400x magnification. (5E) Significative differences of the treated groups in the neuron density of Cal area; where GI $x$ GIII $(*=p<0,05) e G I x G I V(* *=p<0,01)$.

Nonetheless, the hippocampal area $\mathrm{Ca} 3$ presented no difference regarding neuronal density, as it can be observed in Table 2 and Figure 6. 

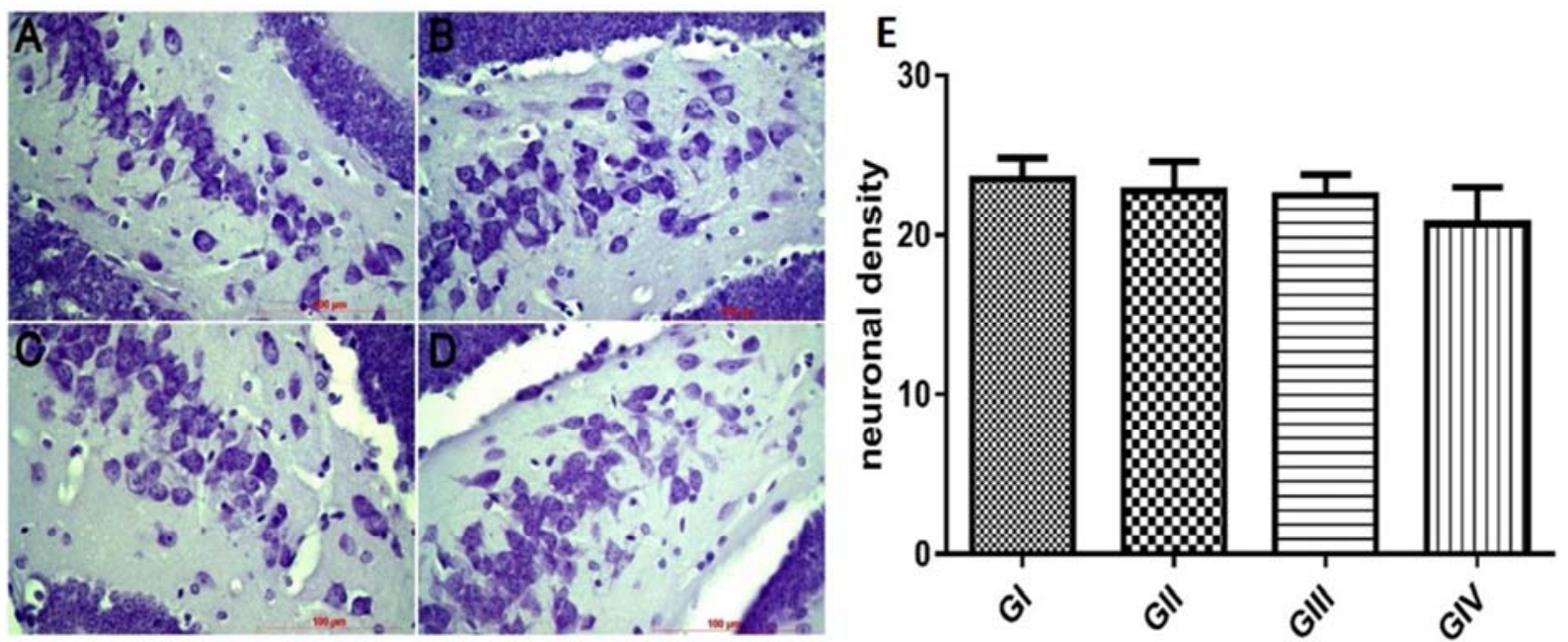

Figure 6. Photomicrography of the Ca3 area from the different groups. A: GI, B: GII, C: GIII e D: G IV. Staining used: Cresil violet. 400x magnification. (6E) No difference regarding of the treated groups in the neuron density of $\mathrm{Ca} 3$ area.

\section{Discussion}

The AAS possess, in general, a higher anabolic and lower androgenic activity $[26,27]$. The nandrolone also possesses the $5 \mathrm{a}$ and $5 \mathrm{~b}$ derivatives, but in comparison to testosterone, its anabolic activity is very elevated and its androgenic activity, acutely reduced [28, 29]. Durateston has testosterone derivates as its active ingredient, and it is believed that its anabolic activity in inferior to the Deca-Durabolin, which has nandrolone decanoate as the active ingredient [28]. Considering that the cortical and hippocampal brain regions contain high NMDA and androgenic receptors concentration, and dihydrotestosterone (DHT) increases the binding rate of glutamate to NMDA receptors [30, 31], it can be assumed that most of the testosterone/DHT provided by Durateston has been consumed helping the glutamate receptor binding, not acting in the androgenic receptor, causing neuronal toxicity. This could explain why Durateston caused a lower neuronal loss than Deca-Durabolin. The same thought can be applied to GIV, because once Durateston is used to another finality, it left a high portion of the androgenic receptors free to interact with nandrolone decanoate, causing possibly more damage and leading to the death of the limbic cortex cells.

In a previous study, the effects of testosterone, nandrolone, stanozolol, and gestrinone over NMDA induced excitotoxic neuron death were compared. The study used primary cortex brain cell culture and the data found suggest that high AAS doses increase neuron vulnerability, facilitating cell death [32]. The present work confirms the hypothesis since authors agree that the steroids exhibit cytotoxic activity that results in neuron death. These research confirms such results since it is believe the steroids show cytotoxic activity, leading to cell death.

A study performed in rats treated with stanozolol for four weeks has shown that the drug can diminish the amounts of dopamine and serotonin in the prefrontal cortex and also reduce serotonin in the hippocampus [33]. The decrease in such neurotransmitters in the prefrontal cortex is associated with the rise of depression $[34,35,36]$. The reduction in the amount of the neurotransmitters can be related to a problem in the synthesis mechanism. The results of the present work, the animals were treated for eight weeks, suggests that the damage caused to the neurons can go beyond interferences in neurotransmitters synthesis, but can also cause cell death, when exposed to the AAS for extended periods.

Mice treated for 28 days with $15 \mathrm{mg} / \mathrm{kg}$ of nandrolone decanoate presented a significant reduction in the number of transcripts htrla, htr1b, htr2a, and htr7 (serotonin receptor genes) in the prefrontal cortex. Besides, the animals presented a $36.6 \%$ reduction in the number of the transcript htr $1 \mathrm{~b}$ in the hippocampus [29]. It can be suggested that the decrease in these receptors can also be associated with the reduction in the neuronal density of the animals treated with nandrolone decanoate, as shown in the present work.

In face of the results obtained in the brain cortex, it can mean the chronic treatment with the specified AAS doses of this work contributed to the reduction of neuron number in the limbic, motor and sensitive areas of the cortex, like the results of previous researches [13, 37], were the anabolic steroids demonstrated association with neuronal loss in the same regions of the brain cortex.

Testosterone has a fundamental role in the growth and cell differentiation. In neurons, the hormone acts inducing alterations at the cell level that can lead to changes in behavior, mood, and memory [38]. Testosterone can be both neuroprotective or neurodegenerative. Neuroblastoma cells treated with high concentrations of the hormone for short time periods demonstrated a reduction in cell viability through apoptosis activation. This can be triggered by intracellular $\mathrm{Ca} 2+$ excess, caused by testosterone [39]. In the same way, it can be assumed high AAS doses for long periods of time can induce apoptosis in the healthy neurons.

The hippocampus is of great importance in learning and memory. Besides, it contributes to the regulation of emotion and aggressivity. Studies demonstrate a role of anabolic steroids in serotonin modulation, resulting in a reduction of $5 \mathrm{HT} 1 \mathrm{~B}$ receptors density and alterations in the GABAergic 
hippocampal system $[40,41]$. Since AAS can cause a decrease in the receptors and change essential systems, it is believed that high doses, chronically administered can lead to cell death in Ca1 and not only receptors loss [42, 43].

Nandrolone decanoate can cause a reduction in the mRNA expression of the NR2A and NR2B subunits of the Nmethyl-d-aspartate (NMDA) receptor in the hippocampus. It can also affect the neurochemical profile of the receptor creating critical behavioral implications [31]. Since the nandrolone decanoate can cause a reduction in the receptors mRNA expression, it is believed that it can also cause a reduction in the number of cells in $\mathrm{Ca} 2$ via mRNA interference in vital cell components, which could explain the decline in neuron numbers in animals from group III and IV.

Just like the results of the limbic area, the results in $\mathrm{Ca} 2$ showed that group II, treated with Durateston does not demonstrate any reduction in neuron numbers when compared to control. That can suggest that the responsibility for the neuron reduction in the animals in group IV is the association of the steroids, which probably potentialized the effects of these substances [28, 29, 44].

Area $\mathrm{Ca} 3$ did not present neuron number reduction as observed in the other observed hippocampal areas. Some recent articles demonstrate exercise-induced neurogenesis capacity in male rats $[45,46]$ these findings may suggest two reasons why there was no significative neuronal density reduction in $\mathrm{Ca}$ 3: a- There was a probable neuronal loss that was counterbalanced by the exercise-stimulated neurogenesis; $b$ - The exercise acted preventing neuron loss.

A few studies demonstrated that NMDA in male rat hippocampus regulates the signaling pathways responsible for synaptic plasticity, which is very important for the hippocampal functions [30]. AAs use causes a reduction in NMDA receptors, reducing synaptic plasticity, but not necessarily the number of neurons in CA3 as observed in the results. It can suggest that there was no reduction in the neuron number because no vital component of the cells was compromised.

Beyond the AAS effects provoked in the central nervous system, researches indicate a high number of deleterious effects in other systems, like hepatotoxicity, cardiomyopathy, gonadal dysfunction, and other effects, like depression [16, $33,47,48]$.

\section{Conclusion}

Following the data presented in this study, it is possible to suggest that: the use of AAS Durateston (testosterone propionate, testosterone phenylpropionate, testosterone isocaproate, testosterone decanoate) and Deca-Durabolin (nandrolone decanoate) caused a reduction in the neuronal density in the limbic, sensitive, and motor areas of male mice brain cortex and $\mathrm{Ca} 1$ and $\mathrm{Ca} 2$ hippocampal regions. Nevertheless, there was no significative difference in the $\mathrm{Ca} 3$ hippocampal area.

In general, both the steroids caused a relevant neuronal loss. However, Deca-Durabolin caused an even more pronounced reduction in some areas when compared to Durateston. Regarding groups treated with both AAS, there was a significative reduction in neuronal density in all regions analyzed, except $\mathrm{Ca} 3$. Based on this, the authors agree that the concomitant use of these anabolic steroids, so common in gyms, can cause damages even more severe than the individual use of the substances.

\section{Conflict of Interest}

The authors declare that they have no conflict of interest.

\section{References}

[1] G. Kanayama, J. I. Hudson, H. G. Pope Jr. Illicit Anabolic Androgenic Steroid Use. Horm Behav, 58 (2010) 111-121. doi: 10.1016/j.yhbeh.2009.09.006.

[2] E. Ozcagli, M. Kara, T. Kotil, P. Fragkiadaki, M. N. Tzatzarakis, C. Tsitsimpikou, P.D. Stivaktakis, D. Tsoukalas, D. A. Spandidos, A. M. Tsatsakis, B. Alpertunga. Stanozolol administration combined with exercise leads to decreased telomerase activity possibly associated with liver aging, 42 (2018) 405-413. doi: 10.3892/ijmm.2018.3644.

[3] S. D. Althobiti, N. M. Alqurashi, A. S. Alotaibi, T. F. Alharthi, K. A. Alswat. Prevalence, Attitude, Knowledge, and Practice of Anabolic Androgenic Steroid (AAS) Use Among Gym Participants, 30 (2018) 49-52. doi: 10.5455/msm.2018.30.4952.

[4] J. A. B. Iriart, J. C. Chaves, R. G. Orlean. Culto ao corpo e uso de anabolizantes entre praticantes de musculação. Cad. Saúde Pública, 25 (2009) 773-782. doi:10.1590/S0102311X2009000400008.

[5] A. Goldman, S. Basaria. Adverse health effects of androgen use, 464 (2018) 46-55. doi: 10.1016/j.mce.2017.06.009.

[6] A. Urhausen, A. Torsten, K. Wilfried. Reversibility of the effects on blood cells, lipids, liver function and hormones in former anabolic-androgenic steroid abusers. J Steroid Biochem Mol Biol, 84 (2003) 369-375.

[7] B. D. Anawalt. Detection of anabolic androgenic steroid use by elite athletes and by members of the general public, 464 (2018) 21-27. doi: 10.1016/j.mce.2017.09.027.

[8] E. Tasgin, S. Lok, N. Demir. Combined usage of testosterone and nandrolone may cause heart damage. African Journal of Biotechnology, $10 \quad$ (2011) 3766-3768. doi: 10.5897/AJB10.2714.

[9] M. Mędraś, A. Brona, P. Jóźków. The Central Effects of Androgenic-anabolic Steroid Use. J Addict Med. 0 (2018). doi: 10.1097/ADM.0000000000000395.

[10] E. Vorona, E. Nieschlag. Adverse effects of doping with anabolic androgenic steroids (AAS) in competitive athletics, recreational sports and bodybuilding. Minerva Endocrinol (2018). doi: 10.23736/S0391-1977.18.02810-9.

[11] K. Y. Salas-Ramirez, P. R. Montalto, C. L. Sisk. Anabolic steroids have long-lasting effects on male social behaviors. Behav Brain Res. 208 (2010) 328-335. doi: 10.1016/j.bbr.2009.11.026. 
[12] R. L. Cunningham, B. J. Claiborne, M. Y. Mcginnis. Pubertal exposure to anabolic androgenic steroids increases spine densities on neurons in the limbic system of male rats. Neuroscience, $150 \quad$ (2007) 609-615. doi: 10.1016/j.neuroscience.2007.09.038.

[13] B. Damião, G. G. Souza, D. A. Nogueira, W. C. Rossi Junior, G. J. M. Fernandes, A. Esteves. Quantificação de corpos de neurônios em camundongos submetidos ao uso de esteroides anabolizantes. Revista de Neurociências, 20 (2012) 68-72.

[14] C. Pomara, M. Neri, S. Bello, C. Fiore, I. Riezzo, E. Turillazzi. Neurotoxicity by synthetic androgen steroids: oxidative stress, apoptosis, and neuropathology: A review. Curr Neuropharmacol, 13 (2015) 132-145. doi: $10.2174 / 1570159 X 13666141210221434$.

[15] A. C. Freitas, B. Damião, D. M. Alves, M. Ribeiro, G. J. M Fernandes, W. C. Rossi Junior, A. Esteves. Efeitos dos anabolizantes sobre a densidade de neurônios dos núcleos da base. Rev Bras Med Esporte, 23 (2017) 213-216. doi:10.1590/1517-869220172303151688.

[16] J. M. Ritter. Sex, steroids and anabolic androgens in athletics. Br J Clin Pharmacol, 74 (2012) 1-2. doi: 10.1111/j.13652125.2012.04329.x.

[17] T. R. Morrison, L. A. Ricci, R. H. Melloni Jr. Anabolic/androgenic steroid administration during adolescence and adulthood differentially modulates aggression and anxiety. Horm Behav, 69 (2015) 132-138. doi: 10.1016/j.yhbeh.2015.01.009.

[18] M. M. Onakomaiya, L. P. Henderson. Mad men, women and steroid cocktails: a review of the impact of sex and other factors on anabolic androgenic steroids effects on affective behaviors. Psychopharmacology, 233 (2016) 549-69. doi: 10.1007/s00213-015-4193-6.

[19] K. J. Brower. Anabolic steroids. Psychiatr Clin North Am, 16 (1993) 97-103.

[20] A. S. Clark, A. S. Fast. Comparison of the effects of 17 alphamethyltestosterone, methandrostenolone, and nandrolone decanoate on the sexual behavior of castrated male rats. Behav Neurosci, 110 (1996) 1478-86.

[21] D. P. Venâncio, A. C. L. Nobrega, S. Tufik, M. T. Melo. Avaliação descritiva sobre o uso de esteroides anabolizantes e seu efeito sobre as variáveis bioquímicas e neuroendócrinas em indivíduos que praticam exercício resistido. Rev Bras Med do Esporte, 16 (2010) 191-195. doi:10.1590/S151786922010000300007 .

[22] West MJ. New stereological method of counting neurons. Neurobiol Aging, 14 (1993) 275-285.

[23] C. A. Mandarim-de-Lacerda. Manual de quantificação Morfológica: Morfometria, Alometria e Estereologia. 2.ed. Rio de Janeiro: CEBIO, 1994.

[24] C. A. Mandarim-de-Lacerda. Stereological tools in biomedical research. An Acad Bras Cien, 75 (2003) 469-486.

[25] B. Pakkenberg, H. J. Gundersen. Neocortical neuron number in humans: effect of sex and age. J Comp Neurol, 384 (1997) 312-20.

[26] A. G. Fragkaki, Y. S. Angelis, M. Koupparis, A. TsantiliKakoulidou, C. Georgakopoulos. Structural characteristics of anabolic androgenic steroids contributing to binding to the androgen receptor and to the anabolic and androgenic activities applied modifications in the steroidal structure. Steroids, $74 \quad$ (2009) 172-197. doi: 10.1016/j.steroids.2008.10.016.

[27] L. L. Brunton, J. S. Lazo, K. L. Parker. The pharmacological basis of therapeutics. Occup Environ Med, 64 (2007). doi:10.1136/oem.2007.033902.

[28] DEF Dicionário de especialidades farmacêuticas. 42 edição, Editora EPUC, 2014.

[29] G. Ambar, S. Chiavegatto. Anabolic-androgenic steroid treatment induces behavioral disinhibition and downregulation of serotonin receptor messenger RNA in the prefrontal cortex and amygdala of male mice. Genes Brain Behav, 8 (2009) 161-173. doi: 10.1111/j.1601-183X.2008.00458.x.

[30] U. L. Rossbach, P. Steensland, F. Nyberg, P. Le Grevés. Nandrolone-induced hippocampal phosphorylation of NMDA receptor subunits and ERKs. Biochem Biophys Res Commun, 357 (2007) 1028-1033. doi: 10.1016/j.bbrc.2007.04.037.

[31] P. Le Grevès, W. Huang, P. Johansson, M. Thörnwall, Q. Zhou, F. Nyberg. Effects of an anabolic-androgenic steroid on the regulation of the NMDA: receptor NR1, NR2A e NR2B subunit mRNAsin brain regions of the male rat. Neurosci Lett, 226 (1997) 61-64. doi: 10.1016/S0304-3940 (97) 00244-9.

[32] R. Orlando, A. Caruso, G. Molinaro, M. Motolese, F. Matrisciano, G. Togna, D. Melchiorri, F. Nicoletti, V. Bruno. Nanomolar concentrations of anabolic androgenic steroids amplify excitotoxic neuronal death in mixed mouse cortical cultures. Brain Research, 65 (2007) 21-29. doi: 10.1016/j.brainres.2007.06.047.

[33] P. Tucci, M. G. Morgese, M. Colaianna, M. Zotti, S. Schiavone, V. Cuomo. Neurochemical consequence of steroid abuse: stanozolol-induced monoaminergic changes. Steroids, 77 (2012) 269-75. doi: 10.1016/j.steroids.2011.12.014.

[34] K. Mizoguchi, A. Ishige, S. Takeda, M. Aburada, T. Tabira. Endogenous glucocorticoids are essential for maintaining prefrontal cortical cognitive function, 24 (2004) 5492-9. doi:10.1523/JNEUROSCI.0086-04.2004.

[35] O. Berton, E. J. Nestler. New approaches to antidepressant drug discovery beyond monoamines. Nat Rev Neurosci, 7 (2006) 137-151. doi:10.1038/nrn1846.

[36] I. Volman, A. K. von Borries, B. H. Bulten, R. J. Verkes, I. Toni, K. Roelofs. Testosterone modulates altered prefrontal control of emotional actions in psychopathic offenders $(1,2$, 3). eNeuro, 3 (2016). doi: 10.1523/ENEURO.0107-15.2016.

[37] A. Bjørnebekk, K. B. Walhovd, M. L. Jorstad, P. DueTennessen, I. R. Hullstein, A. M Fjell. Structural brain imaging of long-term anabolic-androgenic steroid users and nonusing weightlifters. Biol Psychiatry. 82 (2017). doi:10.1016/j.biopsych.2016.06.017.

[38] D. Struik, P. Fadda, T. Zara, E. Zamberletti, T. Rubino, D. Parolaro, W. Fratta, L. Fattore. The anabolic steroid nandrolone alters cannabinoid self-administration and brain CB1 receptor density and function. Pharmacol Res, 115 (2017) 209-217. doi: 10.1016/j.phrs.2016.11.031.

[39] M. Estrada, A. Varshney, B. E. Ehrlich. Elevated testosterone induces apoptosis in neuronal cells. J. Biol. Chem, 281 (2006) 25492-25501. doi:10.1074/jbc. M603193200. 
[40] A. M. Kindlundh, J. Lindblom, L. Bergstrom, F. Nyberg. The anabolic-androgenic steroid nandrolone induces alterations in the density of serotonergic 5HT1B and 5HT2 receptors in the male rat brain. Neuroscience, 119 (2003) 113- 120.

[41] D. Selakovic, J. Joksimovic, I. Zaletel, N. Puskas, M. Matovic, G. Rosic. The opposite effects of nandrolone decanoate and exercise on anxiety levels in rats may involve alterations in hippocampal parvalbumin-positive interneurons. PLoS One. 12 (2017) e0189595. doi: 10.1371/journal.pone.0189595.

[42] B. Ramachandran, S. Ahmed, N. Zafar, C. Dean. Ethanol inhibits LTP in hippocampus CA1 neurons, irrespective of lamina and stimulus strength, through neurosteroidogenesis. Hippocampus, 25 (2015) 106-118. doi: 10.1002/hipo.22356.

[43] F. Ma, D. Liu. 17beta-trenbolone, an anabolic-androgenic steroid as well as an environmental hormone, contributes to neurodegeneration. Toxicol Appl Pharmacol, 282 (2015) 6876. doi: 10.1016/j.taap.2014.11.007.
[44] E. L. Stevenson, H. K. Caldwell. Lesions to the CA2 region of the hippocampus impair social memory in mice. Eur $\mathrm{J}$ Neurosc, 40 (2014) 3294-3301. doi: 10.1111/ejn.12689.

[45] M. Okamoto, Y. Hojo, K. Inoue, T. Matsui, S. Kawato, B. S. McEwen, H. Soya. Mild exercise increases dihydrotestosterone in hippocampus providing evidence for androgenic mediation of neurogenesis. PNAS, 109 (2012) 13100-13105. doi: 10.1073/pnas.1210023109.

[46] S. Joukar, R. Vahidi, A Farsinejad, M. Asadi-Shekaari, B. Shahouzehi. Ameliorative effects of endurance exercise with two different intensities on nandrolone decanoate-induced neurodegeneration in rats: involving redox and apoptotic systems. Neurotox Res. 32 (2017) 41-49. doi: 10.1007/s12640-017-9705-1.

[47] R. C. Agis-Balboa, F. Pibiri, M Nelson, G Pinna. Enhanced fear responses in mice treated with anabolic androgenic steroids. Neuroreport, 20 (2009) 617-621. doi: 10.1097/WNR.0b013e32832a2393. 